\title{
IDEA SYSTEMS FOR INTRAPRENEURSHIP AND GROWTH OF INNOVATION: A LITERATURE REVIEW.
}

Tainah Azevedo Silva ${ }^{a}$, Ingrid Winkler ${ }^{b}$

a Senai Cimatec University Center, Orlando Gomes Avenue, 1845 - Piatã, Salvador, BA, 41650-010, Brazil, tainah1903@gmail.com

b Senai Cimatec University Center, Orlando Gomes Avenue, 1845 - Piatã, Salvador, BA, 41650-010, Brazil, ingrid.winkler@fieb.org.br

Abstract: In the current business context, it is necessary to innovate. Research has shown that idea systems can promote intrapreneurship and innovation. This study aims to identify opportunities to promote innovation through intrapreneurship, using idea systems. Based on a systematic review of the literature, foundations of Capes and ScienceDirect, eleven articles were relevant that pointed out opportunities to obtain innovation with the use of this system. With these references, the system appears to be strategic, but ways of rewarding and aligning with corporate strategy must be considered. Further research is needed to identify factors such as motivation and types of innovation obtained.

Keywords: Innovation; Idea System; Suggestions program; Intrapreneurship; Intrapreneur.

\section{SISTEMAS DE IDEIAS PARA O INTRAEMPREENDEDORISMO E CRESCIMENTO DA INOVAÇÃO: UMA REVISÃO DA LITERATURA.}

Resumo: No atual contexto empresarial é necessário inovar. A pesquisa mostrou que o sistema de ideias pode promover o intraempreendedorismo e a inovação. Este estudo tem como objetivo identificar oportunidades de promoção da inovação por meio do intraempreendedorismo, utilizando o sistema de ideias. Com base em uma revisão sistemática da literatura, bases da Capes e ScienceDirect, foram relevantes onze artigos que apontaram oportunidades de obter inovação com a utilização desse sistema. Com estas referências, o sistema parece ser estratégico, mas devem ser consideradas as formas de recompensa e o alinhamento com a estratégia corporativa. Mais pesquisas são necessárias para identificar fatores como motivação e tipos inovação obtidas.

Palavras-chave: Inovação; Sistema de ideias; Programa de sugestões; Intraempreendedorismo; Intraempreendedor. 


\section{INTRODUCTION}

Similar to living beings, organizations will go through a life cycle in different stages: birth, childhood, adulthood and old age. In some stages, such as adulthood, the organization has a well-defined position and strategy, inducing it to a state of stability that makes it less sensitive to innovation. Regardless of the phase an organization is in, innovating is strategic for it to be promising [1].

Understanding the concept of innovation is essential for the purpose of this subject. It a complex concept with multiple types and dimensions. Without promoting innovation, there is a great risk of discontinuity, which can put an early end to a company or market segment [2].

An innovation is a new or improved product or process (or combination thereof) that differs significantly from the unit's previous products or processes and that has been made available to potential users (product) or brought into use by the unit (process) [2].

In this complex scenario, which requires constant differentiation from companies, intrapreneurship seems to maintain organizational health. The intrapreneur represents the one who, within the organization, takes on the responsibility of promoting innovation, regardless of his position or time in the company. The contributions they can make merit attention to details and management involvement.

Idea systems are a set of practices aimed at internal entrepreneurship, where the entire organization is involved and contributes with suggestions for continuous improvement and innovation. Depending on the organizational structure, they can count on software or programs where these ideas are placed and managed in terms of feasibility and possible rewards. Other practices such as idea workshops and engagement in projects for specific demands can also be part of these systems [3].

Modeling a high-performance idea management system (IMS) goes beyond the limits of suggestions and also encourages the identification of problems [3]. If employees are aligned with the corporate strategy, the chances of this program being effective and bringing growth to the organization's innovative capacity increases considerably [4]. Thus, idea system, IMS or suggestion program all function as similar expressions for understanding this article, and, when well outlined, it can be used as catalysts for corporate innovation. This tool is a part of the strategic management of innovation. The actions cannot be accidental or seasonal, for them to bring real competitive advantage they need to be permanent and systematized.

Thus, the study aims to characterize the current knowledge about intrapreneurship and idea systems, as well as the possible benefits of using these systems in organizations. Recognizing that innovation can arise from all people tends to enhance the ability to obtain innovative results. These still provide the record of the suspicions that are often derived from the experience of those who perform or are just a good observer, revealing intrapreneurs.

Studying these programs is relevant for organizations and leaders, who must be sensitive to market changes and periodically reevaluate strategies and 
can rely on an internal collection of suggestions with potential for innovation. For academics, there is the possibility to refine the methods, extract trends and analyze where there are greater potential sources or how to leverage existing ones. This paper is organized as follows. Section 2 describes the Methodology. Sections 3 discuss the Results observed in the study. Finally, Section 4 presents our Conclusions and further research needed.

\section{METHODOLOGY}

This is an exploratory research, in this paper, four steps were followed; Planning, Search, Selection and Synthesis.

A. Planning: In this step the guiding questions were delimited. Are they:

Q1: What is the state of the art on idea system as a facilitator of intrapreneurship?

Q2: What are the limitations and opportunities in applying this system? Can it effectively increase the capacity for business innovation?

Next the definition of the databases follows. Those used in this work were Capes and ScienceDirect. These databases are easily accessible, free and have a wide range of publications in the management area. The keywords were selected with the intention of refining the searches and making them more precise.

B. Search: The searches in the databases were carried out with the keywords in English and Portuguese:

("Intrapreneurship" OR "Intrapreneur") AND ("Innovation). ("Suggestion program" OR "Idea Systems") AND ('Innovation"). ("Suggestion program" OR "Idea Systems") AND ('Intrapreneurship" OR "Intrapreneur").

('Intraempreendedorismo" OR "Intraempreendedor") AND ('Inovação). ("Programa de sugestões" OR "Sistemas de ideias") AND ("Inovação"). ("Programa de sugestões" OR "Sistemas de ideias") AND ("Intraempreendedorismo" OR "Intraempreendedor").

The search period was limited to 2014 to 2019. When the searches brought articles from the medical or information technology areas only peerreviewed documents were considered. The search brought a total of 1,186 works with some of the terms in the title or abstract.

C. Selection: Exclusion criteria adopted and titles that contained some of the terms, but involved machines, computers, hospitals and universities, were disregarded. Reading the abstracts showed that they deviated from the main problem and were therefore excluded. After this stage, the number of related articles became 56. In a new reading of the abstracts and introductions, in order to seek even more connection with the theme, 11 articles were elected as the most complete to support the research. These helped in the construction of the arguments of the proposed discussion. Figure 1 shows the selection path: 
Figure 1. Selection of works

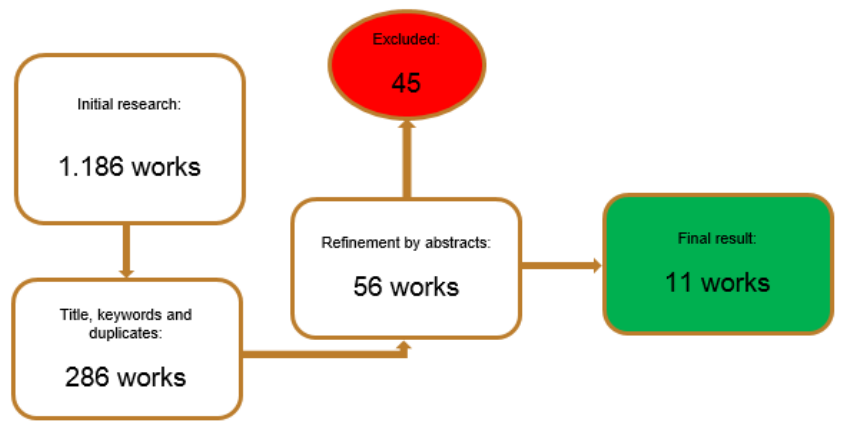

Source: Elaboration of the authors

D. Synthesis: At this stage, the 11 selected works were analysed to group the information presented.

\section{RESULTS AND DISCUSSION}

Results of the systematic review will be presented to answer the guiding questions.

Table 1. Table title

\begin{tabular}{|c|c|c|}
\hline $\begin{array}{c}\text { REFERENCE } \\
\text { OF THE } \\
\text { WORKS }\end{array}$ & AUTHOR & TITLE \\
\hline [5] & $\begin{array}{l}\text { MACEDO Morais, Greiciele, } \\
\text { et al. }\end{array}$ & INTRAPRENEURSHIP, INNOVATION AND COMPETITIVENESS IN ORGANIZATIONS. \\
\hline [6] & $\begin{array}{c}\text { ORCHARDT, Pietra; } \\
\text { SANTOS, Glicia Vieira dos. }\end{array}$ & $\begin{array}{l}\text { MANAGEMENT OF IDEAS FOR INNOVATION: TRANSFORMING CREATIVITY INTO } \\
\text { PRACTICAL SOLUTIONS. }\end{array}$ \\
\hline [7] & $\begin{array}{l}\text { QUANDT, Carlos Olavo, et } \\
\text { al. }\end{array}$ & $\begin{array}{c}\text { IDEAS AND INNOVATION MANAGEMENT PROGRAMS: THE PRACTICES OF LARGE } \\
\text { COMPANIES IN SOUTHERN BRAZIL. }\end{array}$ \\
\hline [8] & $\begin{array}{l}\text { SPITZECK, Heiko Hosomi, } \\
\text { et al. }\end{array}$ & AWAKENING THE POWER OF IMPACT INTRA-ENTREPRENEURSHIP IN BRAZIL \\
\hline [9] & PRIETO, Leon C, et al. & $\begin{array}{l}\text { FACILITATING A CULTURE OF INTRAPRENEURSHIP: AN EMPLOYEE } \\
\text { INVOLVEMENT APPROACH. }\end{array}$ \\
\hline [10] & FALOLA, Hezekiah, et al. & $\begin{array}{c}\text { EMPLOYEES' INTRAPRENEURIAL ENGAGEMENT INITIATIVES AND ITS INFLUENCE } \\
\text { ON ORGANISATIONAL SURVIVAL. }\end{array}$ \\
\hline [11] & CORDEIRO, Luana Bettu. & INTRAPRENEURSHIP: STRATEGY FOR THE INNOVATION OF ORGANIZATIONS. \\
\hline [12] & $\begin{array}{l}\text { BRUNO, Fátima; FONSECA, } \\
\text { Marcus. }\end{array}$ & $\begin{array}{l}\text { MEASURE OF THE CULTURE OF INNOVATION: A SYSTEMATIC AND STRATEGIC } \\
\text { APPROACH FOCUSING ON THE EFFECTIVENESS OF INNOVATION. }\end{array}$ \\
\hline [13] & $\begin{array}{l}\text { RODRIGUES, Daniel; } \\
\text { TEIXEIRA, Rafael. }\end{array}$ & $\begin{array}{l}\text { THE CONTRIBUTIONS OF CORPORATE ENTREPRENEURSHIP TO THE } \\
\text { IMPLEMENTATION OF STRATEGIES. }\end{array}$ \\
\hline [14] & VALLADARES, Paulo, et al. & INNOVATION CAPABILITY: A SYSTEMATIC REVIEW OF THE LITERATURE. \\
\hline [15] & GAWKE, Jason C, et al. & $\begin{array}{l}\text { MEASURING INTRAPRENEURSHIP AT THE INDIVIDUAL LEVEL: DEVELOPMENT } \\
\text { AND VALIDATION OF THE EMPLOYEE INTRAPRENEURSHIP SCALE (EIS). }\end{array}$ \\
\hline
\end{tabular}


A.Q1: What is the state of the art in relation to systems of ideas as a facilitator of intrapreneurship?

Systems of ideas or suggestion programs are a set of rules so that all employee contributions are stored, analyzed, put into practice and, depending on the policy adopted, rewarded. According to the literature this is not such a recent tool. The first records of the practice came from Japan, in the mid-1980s they were called Kaizen Teian [3,6]. Kaizen Teian systems are similar to the implementation of a suggestion box. There is encouragement for the participation of all employees and any idea is welcome. With the concept brought to other nationalities, the programs have been adapted and even gain some degree of computerization [7].

Some authors point out that collaborators are not obliged to suggest $[6,7$, 15]. The ideation process needs to be stimulated and recognized. It is a sensitive flow that is influenced by various organizational aspects such as climate and motivation $[4,8,9,11,15]$. There does not seem to be a single model, but rather principles to consider, largely linked to innovation management [5]. Without a system, however rustic, suggestions can become a nuisance since each idea can receive a different approach and perhaps the most innovative one is neglected [4]. Most of the researched works do not deal with the use of these systems specifically $[5,8,9,10,11,13,14]$. Whether due to the lack of openness for a survey at this level or because the tool is not a specific model, but adaptable to each structure and often, even though the organization is not guided by ideas, there is an informal channel to capture these opinions $[6,7]$.

A high-performance IMS is not just a way to gather employee suggestions. It is a marriage with the culture of innovation, entrepreneurship and knowledge management $[2,5,9,11]$. To achieve the expected objective, programs need to be monitored and opportunities for improvement identified. Some measures reported in the studies as indispensable for monitoring are the amount of ideas, their origin and the speed of use $[6,7,12,15]$. Managing innovation means practicing search, selection, implementation and learning $[5,7,12]$.

In the context of industry 4.0 , the use of technological tools can offer increasingly stimulating experiences to employees in these programs. Using virtual reality for this type of action, with spaces dedicated to immersion in problem situations or in playful activities, such as games, can favor creativity and promote innovation [6]. According to studies [6,7,12,15], the use of suggestion programs can assist in the identification of intrapreneurs, promote a culture of innovation, create opportunities to unlock potential employees who would not have the opportunity to contribute with their ideas, establish recognition parameters, stimulate creativity, collaboration, team work and the sense of attitude of the owner.

In Brazil we find reports from organizations that recognize the importance of corporate entrepreneurship [2,8,14]. In one of the works found, the experience in the southern region showed that, albeit with some inhibition, innovative activities such as a suggestion program have already gained their space [7]. The work of the Center for intrapreneurship also highlighted in its report, 2019, the intention of large companies to exercise employee suggestions [8].

Q2: What are the limitations and opportunities in applying these systems, can they effectively increase the capacity for business innovation? 
The main limitations to a system of ideas seem to be the same as for a culture focused on innovation [7]. The studies [5,11,14] describe the culture of innovation as a strategic decision that will guarantee the constant renewal and growth of the organization, as well as the implementation of an IMS is a commitment of the entire company and a decision that needs to be aligned with the path that the organization wants to take to achieve your goals [9]. Some of the barriers found in the literature for the application of these systems were: time and financing $[3,6,7]$. In the first impediment, time, managers need to manage how much their employees will invest in the application of their ideas. With routines, goals and deadlines that are often fully committed, there is no time to work on your suggestions $[3,6,7]$. Another major impediment may be the financing of resources for the implementation of ideas. Bureaucratic purchasing processes and very tight budgets can inhibit suggestors[3,6,7].

Other barrier may be familiarity with the resources made available. The organization can offer a complex integrated system to capture ideas, but its employees are not familiar with technology $[6,7]$. Or even work so simply that it does not offer confidence in the integrity of the program. Else essential point is the commitment of top leadership to the system. Without this commitment, there may be no continuity in the actions. It would be a divided organization and soon the creative process would be inhibited. The idea systems would return to the suggestion box status [3, 6,7,12]. One last critical, factor is the uncertainty. Innovative activities may not have the expected result, and this means spending resources, time and losing credibility $[4,9,13]$. However, failure can be part of the application of ideas and, due to different factors, even external to the organization, may render the desired result unfeasible. However, any deviation should imply improvements for the next attempts and serve as learning $[6,7]$. As for the opportunities in the use of IMS, there seem to be several, such as: the creation of a bank of ideas, the engagement of employees, an increase in the pace of innovation, the discovery of opportunities, cost reduction and process optimization $[6,7,12]$.

In the state of the art, it is evident that intrapreneurship is strategic in order to be competitive and enhance the growth of the companies' innovative capacity [10]. The use of a suggestion program can organize, facilitate control and equity in assessments, reinforcing the role of the intrapreneur [6]. The use of previously established policies tends to avoid inequality and misalignment in the use of resources. A good system balances the suggestor's imagination with the viability of an idea [7]. An IMS that encourages and implements ideas, be they big or small, seems to be a strategic learning and development tool since it can offer advantages that differentiate an organization that does only the basics from another highly successful one [3,6,7]. Frontline suggestions, at an operational level, tend to provide a strong competitive base, as they are directly linked to a specific company's situation and which would rarely have application in other corporations [3].

\section{CONCLUSION}

This work aimed to search literature for evidence that management systems can facilitate intrapreneurship, enhancing the organization's capacity to 
innovate. The observed results show the recognition of the intrapreneur as an innovation agent, but little was reported about the practices related to ideas systems. Intrapreneurship has assumed great importance in obtaining competitive advantage in the current context, but there seems to be little cataloged data on the systematization of innovative activities directly related to the suggestion programs [2,5,8,11]. From the authors found, it is certain that innovation and corporate entrepreneurship go together, and the collaborators of this century need to understand that innovation is the most effective way to renew and leverage organizations [11].

Further research it is suggested to deepen the application of suggestion systems in Brazilian companies, in the most diverse segments. There is also a gap in measuring the levels of innovation obtained with the programs and the degree of use of the suggestions consolidated in these systems.

\section{REFERENCES}

${ }^{1} \mathrm{HASHIMOTO}$, Marcos. ENTREPRENEURIAL SPIRIT IN ORGANIZATIONS: increasing competitiveness through intrapreneurship. 2. ed. São Paulo: Saraiva, 2010. 320 p.

${ }^{2}$ OECD/Eurostat (2018), Oslo Manual 2018: Guidelines for Collecting, Reporting and Using Data on Innovation, 4th Edition, The Measurement of Scientific, Technological and Innovation Activities, OECD Publishing, Paris/Eurostat, Luxembourg.https://doi.org/10.1787/9789264304604-en.

${ }^{3}$ ROBINSON, A. G.; SCHROEDER, D.M. ORGANIZATION GUIDED BY IDEAS: innovation from all people. São Paulo: M. Books, 2016.240 p.

${ }^{4}$ KUENNE, Chris; DANNER, John. MADE TO GROW: how intraentrepreneurship can promote innovation and business development. São Paulo: Hsm, 2018. 269 p.

5MACEDO Morais, Greiciele; Santos, Valdeci; Tolentino, Renata. (2019). Intrapreneurship, Innovation and Competitiveness in Organizations. https://www.researchgate.net/publication/334308315. Accessed on 24 July. 2020.

${ }^{6}$ ORCHARDT, Pietra; SANTOS, Glicia Vieira dos. MANAGEMENT OF IDEAS FOR INNOVATION: transforming creativity into practical solutions. Review of Administration and Innovation - Rai, [S.L.], v. 11, n. 1, p. 203, Apr. 13, 2014. Faculty of Economics, Administration and Accounting. http://dx.doi.org/10.5773/rai.v11i1.1185. Available at: https://www.sciencedirect.com/science/article/pii/S1809203916301413.

Accessed on 23 jul. 2020.

${ }^{7}$ QUANDT, Carlos Olavo; SILVA, Helena de Fátima Nunes; FERRARESI, Alex Antonio; FREGA, José Roberto. IDEAS AND INNOVATION MANAGEMENT PROGRAMS: the practices of large companies in southern Brazil. Review of Administration and Innovation - Rai, [S.L.], v. 11, n. 3, p. 176, Nov 62014. University of Sao Paulo, USP Academic Information Management Agency 
(AGUIA). http://dx.doi.org/10.11606/rai.v11i3.100220. Available at: https://www.researchgate.net/publication/269104966. Accessed on 23 Jul. 2020.

${ }^{8}$ SPITZECK, Heiko Hosomi; ESTRADE, Florencia; CAMPOS, Alda Marina. AWAKENING THE POWER OF IMPACT INTRAPRENEURSHIP IN BRAZIL. São Paulo: Center for Intrapreneurship, 2019. 59 p. Available at: https://nucleos.fdc.org.br/sustentabilidade/centro-de-intraempreendedorismo/. Accessed on 26 July. 2020.

${ }^{9}$ PRIETO, Leon C.; PHIPPS, Simone T.A.; KUNGU, Kenneth. Facilitating a culture of intrapreneurship: an employee involvement approach. Strategic $\mathrm{Hr}$ Review, [S.L.], v. 19, n. 2, p. 93-95, 1 abr. 2020. Emerald. http://dx.doi.org/10.1108/shr-04-2020-181. Disponível em: https://www.researchgate.net/publication/340695830. Acesso em: 23 jul. 2020.

${ }^{10} \mathrm{FALOLA}$, Hezekiah O.; SALAU, Odunayo P.; OLOKUNDUN, Maxwell A.; OYAFUNKE-OMONIY, Comfort O.; IBIDUNNI, Ayodotun S.; OSIBANJO, Omotayo A. EMPLOYEES' INTRAPRENEURIAL ENGAGEMENT INITIATIVES AND ITS INFLUENCE ON ORGANISATIONAL SURVIVAL. Business: Theory and Practice, [S.L.], v. 19, p. 9-16, 2 fev. 2018. Vilnius Gediminas Technical University. http://dx.doi.org/10.3846/btp.2018.02. Disponível em: https://www.researchgate.net/publication/322903351. Acesso em: 23 jul. 2020.

${ }^{11}$ CORDEIRO, Luana Bettu. INTRA-ENTREPRENEURSHIP: STRATEGY FOR THE INNOVATION OF ORGANIZATIONS. Revista Livre de Sustentabilidade e Empreendedorismo, São Paulo, Vol. 1, n. 3, p. 151-178, Oct 18 2016. Available at: https://www.researchgate.net/publication/334308315. Accessed on 23 Jul. 2020.

${ }^{12}$ BRUNO, Fátima; FONSECA, Marcus. (2014). Innovation culture and organizational culture measures for analyzing the association with innovation. RAI - Magazine of Administration and Innovation. http://dx.doi.org/ 11.30-55.10.5773/rai.v11i3.1004. Available at: https://www.researchgate.net/publication/272144186. Acesso em: 23 jul. 2020.

${ }^{13}$ RODRIGUES, Daniel; TEIXEIRA, Rafael. The Contributions of Corporate Entrepreneurship to the Implementation of Strategies. Ibero-American Journal of Strategy, [S.L.], v. 14, n. 01, p. 60-75, 1 mar. 2015. University Nove de Julho. http://dx.doi.org/10.5585/riae.v14i1.2050. Available at: https://www.researchgate.net/publication/282199543 Accessed on 23 jul. 2020.

${ }^{14}$ VALLADARES, Paulo Sergio Duarte de Almeida; VASCONCELLOS, Marcos Augusto de; SERIO, Luiz Carlos di. Innovation Capacity: systematic literature review. Revista de Administração Contemporânea, [S.L.], v. 18, n. 5, p. 598-626, set. 2014. FapUNIFESP (SciELO). http://dx.doi.org/10.1590/19827849rac20141210. Available

at: https://www.researchgate.net/publication/279290388. Accessed on 23 jul. 2020.

${ }^{15}$ GAWKE, Jason C.; GORGIEVSKI, Marjan J.; BAKKER, Arnold B. Measuring intrapreneurship at the individual level: development and validation of the employee intrapreneurship scale (eis). European Management Journal, [S.L.], v. 37, n. 6, p. 806-817, ten. 2019. Elsevier BV. http://dx.doi.org/10.1016/j.emj.2019.03.001. Available at: https://www.researchgate.net/publication/331475606. Accessed on 23 jul. 2020. 